HENSCHEL, JM; RESENDE, JTV; GILONI-LIMA, PC; ZEIST, AR; LIMAFILHO, RB; SANTOS, MH. 2017. Production and quality of strawberry cultivated under different colors of low tunnel cover. Horticultura Brasileira 35: 364-370. DOI - http://dx.doi.org/10.1590/S0102-053620170308

\title{
Production and quality of strawberry cultivated under different colors of low tunnel cover
}

\author{
Juliane M Henschel; Juliano TV Resende; Patrícia C Giloni-Lima; André R Zeist; Renato B Lima Filho; \\ Matheus H Santos \\ Universidade Estadual do Centro-Oeste (UNICENTRO), Guarapuava-PR, Brasil; juliane_henschel@hotmail.com; jvresende@uol.com.br; \\ pgiloni2012@gmail.com; andre.zeist@bol.com.br; renatinho_barros@yahoo.com.br; matheushermann1995@hotmail.com
}

\begin{abstract}
Strawberry is a crop of great economic and social importance. Its fruits are appreciated both for their flavor and nutraceutical potential. Some studies confirm that light quality influences plant physiology. Thus, the aim of this study was to investigate if changes in light spectrum, provided by low tunnels, can improve vegetative traits, as well as, production and fruit quality of strawberry. The authors used six tunnel covers (red, yellow, blue, green, transparent and opaque and one control, without cover), and two cultivars: a short photoperiod cultivar (Camarosa) and a neutral photoperiod cultivar (Albion). Experiment was evaluated in two seasons: production and plant development first; and then, post-harvest quality. Overall, Camarosa showed higher vegetative growth, lower production, and better fruit quality than Albion. Due to the complexity of physiological and biochemical responses, each trait evaluated showed a specific response to light changes. The red, blue, yellow and green covers did not show any significant improvement comparing with transparent and opaque covers. Thus, the authors suggest the use of the latter ones which have already been used commercially.
\end{abstract}

Keywords: Fragaria ananassa, light spectrum, light intensity, colored films, photomorphogenesis, photoperiod.

\section{RESUMO}

Produção e qualidade de morangueiro cultivado sob diferentes cores de cobertura de túneis baixos

O morangueiro é uma cultura de grande importância econômica e social. Seus frutos são apreciados tanto pelo sabor como pelo potencial nutracêutico. Estudos confirmam que a qualidade luminosa influencia a fisiologia das plantas. Dessa forma, o objetivo com este trabalho foi investigar se mudanças no espectro luminoso, proporcionadas por coberturas de túneis baixos, podem melhorar características vegetativas, de produção e de qualidade de frutos de morangueiro. Foram utilizadas seis coberturas de túneis (utilizando filme plástico de cores vermelha, amarela, azul, verde, transparente e leitosa e uma testemunha, e duas cultivares: uma de fotoperíodo curto (Camarosa) e uma de fotoperíodo neutro (Albion). O experimento foi avaliado em duas épocas, sendo que, na primeira época foram avaliados produção e desenvolvimento vegetativo, e na segunda época a qualidade pós-colheita. De modo geral, Camarosa apresentou maior desenvolvimento vegetativo, menor produção, e melhor qualidade de frutos que Albion. Devido à complexidade das respostas fisiológicas e bioquímicas das plantas, cada característica avaliada apresentou uma resposta específica à alteração luminosa. As coberturas vermelha, azul, amarela e verde não demonstraram resultados expressivamente superiores aos das coberturas transparente e leitosa, assim, sugere-se a utilização destas, que já são utilizadas comercialmente.

Palavras-chave: Fragaria ananassa, espectro luminoso, intensidade luminosa, filmes coloridos, fotomorfogênese, fotoperíodo.

Received on June 29. 2016; accepted on January 29, 2017

$\mathrm{T}$ he strawberry pseudo-fruit (Fragaria ananassa) is appreciated for its attractive flavor, color and aroma. Besides, it is a source of bioactive compounds such as vitamin $\mathrm{C}$ and $\mathrm{E}$, $\beta$-carotene and phenolic compounds, which characterizes the strawberry as a "functional food" (Basu et al., 2014).

In Brazil, Minas Gerais State is the largest strawberry grower, followed by Paraná and Rio Grande do Sul (Carvalho et al., 2014). Besides being the largest grower, the weather conditions in Minas Gerais allowed production of fruits with high ratio values, reflecting in fruits with quality higher than those produced in the South Region (Resende et al., 2010; Antunes et al., 2014; Pádua et al., 2015). In this sense, searching for alternative growing techniques which aim to improve the fruit quality in this region, maintaining good productivity, is necessary.

The use of low tunnels can be a feasible alternative in order to improve the quality, since the tunnels protect the plants and fruits in regions which have high rainfall, hail and frost, besides reducing the occurrence of diseases, extending the harvest period and avoiding nutrient leaching (Resende et al., 2010). On the other hand, some studies have confirmed the influence of the light quality on plant physiology (Casierra-Posada et al., 2011; CasierraPosada \& Peña-Olmos, 2015), being able to generate improvements like greater production and quality of fruits, due mainly to phytomorphogenic responses of phytochromes (CasierraPosada et al., 2011, 2012). This fact has been stimulating the use of different 
colored materials (shade nets and plastic films) to cover the plants, aiming to change the incident light. Thus, an option to link the physiological benefits to ease of management, lower expenses, better quality and production of fruits is to use low tunnels covered by plastic films which filter different wavelengths.

In this sense, the authors aimed to evaluate the effect of different colored covers, in low tunnels, on vegetative growth, production and fruit quality traits of two strawberry cultivars.

\section{MATERIAL AND METHODS}

The experiment was carried out in Setor de Olericultura do Departamento de Agronomia da Universidade Estadual do Centro-Oeste (Vegetable Crops Sector of Agronomy Department at CentralWest University), in Guarapuava, Paraná State $\left(25^{\circ} 2301 \quad \mathrm{~S}, 51^{\circ} 2946\right.$ $\mathrm{W}$, altitude $1.025 \mathrm{~m}$ ) were the climate is humid subtropical $(\mathrm{Cfb})$. The soil of the area was classified as typical dystrophic South Brazilian Oxisol (Embrapa, 2013).

The experimental design was completely randomized, arranged in a $2 \times 7$ factorial scheme. The treatments consisted of two strawberry cultivars (Camarosa and Albion, short and neutral photoperiod, respectively) and six low tunnel covers (with red, blue, yellow, green, opaque and transparent plastic film and one control, without cover). The experiment was composed of three blocks, each one corresponding to one seedbed (dimensions of $28 \mathrm{~m}$ long and $1.2 \mathrm{~m}$ wide). Each seedbed was divided into plots of $2 \mathrm{~m}^{2}$, in which the low tunnels were installed. In each plot, eighteen seedlings were transplanted, nine of each cultivar, spacing $30 \times 30 \mathrm{~cm}$. In each plot, the authors left free a space of $2.0 \mathrm{~m}$ in order to avoid interference between the treatments.

The strawberry seedlings were obtained from Chile and they were transplanted in the field in July, 2014, carried out in tunnels $(0.8 \mathrm{~m}$ high in the central part, with $1.2 \mathrm{~m}$ wide seedbeds and $0.25 \mathrm{~m}$ high) covered with black polyethylene film. To cover the tunnels, the author used $150 \mu \mathrm{m}$-thick polyethylene films $\left(B R F\right.$ Lonas $\left.^{\circledR}\right)$. Drip irrigation was carried out, according to the crop need, using micro-drippers.

Based on the soil chemical analysis, the authors carried out liming, applying $100 \mathrm{~g}$ of calcitic limestone filler in each $2 \mathrm{~m}^{2}$ plot. For transplanting, 400 $\mathrm{g}$ of simple superphosphate, $50 \mathrm{~g}$ of potassium chloride, $50 \mathrm{~g}$ of urea and $5 \mathrm{~kg}$ of manure were used per plot. The top dressing fertilization was carried out using nitrogen, applying diluted urea $(100 \mathrm{mg} / \mathrm{L})$ and triple superphosphate $\left(27 \mathrm{~g} / \mathrm{m}^{2}\right)$, at 150 days after transplanting. During the reproductive cycle, five foliar sprays with calcium and boron $(3 \mathrm{mg} / \mathrm{L}$ of $\mathrm{CaB}$ $105^{\circledR}$ : Ca $10 \%$ e B 0,5\%) were carried out. The weed control was carried out manually. For the control of pests and diseases, the authors carried out alternate sprays with thiamethoxam $(250 \mathrm{~g} / \mathrm{kg})$, abamectin $(18 \mathrm{~g} / \mathrm{L})$, iprodione ${ }^{\circledR}(500$ $\mathrm{g} / \mathrm{L})$, tiofanato-metílico ${ }^{\circledR}(700 \mathrm{~g} / \mathrm{kg})$ and difenoconazol ${ }^{\circledR}(200 \mathrm{~g} / \mathrm{L})$.

The fruits were harvested at maturation stage, in which $3 / 4$ of the fruit was ripe or showing dark red surface. Harvest was carried out every two days, from September 2014 to February 2015 to evaluate production, and from June to September 2015 to evaluate postharvest traits.

The agronomic traits evaluated were: height of insertion of the leaf $(\mathrm{cm})$, internode etiolation $(\mathrm{cm})$ and stolon emission (stolons per plant). In order to obtain production components, the authors determined: total number of fruits (number of fruits/plant); total mass of fruits per plant ( $\mathrm{g} / \mathrm{plant})$; and average mass of fruits $(\mathrm{g})$.

To determine the physico-chemical analyses, the authors used fully ripe fruits, showing uniform color and size. To determine the color of fruits, the authors used fresh fruits. The rest of the fruits was frozen immediately after harvesting, for subsequent grinding and analysis.

Soluble solid content was determined in triplicate, with the aid of a digital refractometer (model PAL-1\% - ATAGO) and expressed in ${ }^{\circ}$ Brix. The determination of titratable acidity (AT) was carried out in three replications, according to the methodology proposed by Instituto Adolfo Lutz (2005). The results were expressed in grams of citric acid per $100 \mathrm{~g}$ of pulp. The ratio was obtained from the relationship between soluble solid (SS) and titratable acidity (AT) values.

In order to determine the total phenolic compounds and anthocyanins, the authors extracted the crushed pulp, in ethanol $80 \%$. The quantification of total phenolic compounds (mg gallic acid/100 g pulp) was carried out according to spectrophotometric method of Follin-Ciocauteau, proposed by Woisky \& Salatino (1998). Total anthocyanin content $(\mathrm{mg}$ of pelargonidin-3-glycoside/100g of fresh mass) was determined using pH-differential method described by Giusti \& Wrolstad (2001) adapted for strawberry. The ascorbic acid content (vitamin C) was determined by standard titration method of AOAC modified by Benassi \& Antunes (1998). Vitamin C content was calculated based on titration values of standard solution of ascorbic acid and the results expressed in $\mathrm{mg}$ of $10 \mathrm{~g}$ of ascorbic acid/100 $\mathrm{g}$ pulp.

To evaluate the color of the fruits, the authors used a Minolta colorimeter (Chroma Meter CR-400/410, Konica Minolta). The readings were carried out in triplicate in the external and internal equatorial region of the fruits. From the components $\mathrm{L}^{*}, \mathrm{a}^{*}$ and $\mathrm{b}^{*}$, the color saturation was calculated: chroma $=\left(a^{* 2}\right.$ $\left.\mathrm{x} \mathrm{b}^{* 2}\right)^{0,5}$; and color tonality: Hue angle $=\tan b^{*} / a^{*} \times 180 / \pi$.

The data obtained were tested for normality and homogeneity, using the Box Cox transformation for the variables: total mass of commercial fruits, internode etiolation, soluble solid, ascorbic acid, anthocyanins, chroma and internal and external hue. Subsequently, the data were submitted to ANOVA, using the software SISVAR 5.3 (Ferreira, 2010). The averages with significant differences were compared using the Tukey test $(\mathrm{p} \leq 0.05)$.

\section{RESULTS AND DISCUSSION}

Total production components (number and mass of fruits per plant and average mass of fruits), height of trefoil 
insertion, internode etiolation, stolon emission had not provided significant interaction between the variation factors (cover $\mathrm{x}$ cultivar). However, the authors found some significant differences when these factors were evaluated independently.

In relation to the cultivars, Camarosa showed taller trefoil insertion, etiolation and stolon emission than Albion (Figure 1). Besides, Camarosa produced considerably less than Albion (Figure 1), which also showed higher average mass of fruits. This difference may be related to the different physiological behavior of the cultivars, since these traits are sensitive to temperature changes, photoperiod and to the interaction of these factors (Heide et al., 2013). Since Camarosa needs short days and lower temperatures for inducing flowering, in different conditions, this cultivar starts to invest in vegetative growth, mainly in petiole elongation (Durner, 2015).

In this context, as the evaluations occurred from October to January, months in which the days are longer and the temperatures higher, the flowering decreased and the plants start to invest in vegetative growth, justifying the higher heights and stolon emission and lower fruit production of Camarosa. This is due to the antagonism between flowering and vegetative growth, in which, resources for physiological processes become unavailable to others (Stamm \& Kumar, 2010). Similarly, cultivar Albion is classified as insensitive to photoperiod, kept the floral induction and production even in hottest months of the year, in detriment of vegetative development (Heide et al., 2013; Durner, 2015).

The plants which showed less etiolation and greater stolon emission were grown under control and transparent cover treatments, which showed lower opacity (Table 1). This fact shows that the other treatments may have caused a shading effect, which was interpreted by plants as competition for light, which stimulated vegetative growth. Since, in natural environments, the shading caused by neighboring plants change the quantity and quality of radiation which reaches shaded plants (Pierik $\&$ Wit, 2014), which when exposed to such changes in light, may adapt their morphogenesis, photosynthesis and photoprotective mechanisms (Anders \& Essen, 2015). The ability of plants to perceive the environment is due to the action of specific photoreceptors sensitive to different light quality and intensity and, when exposed to different luminous quality, emit signs translated into morphophysiological changes (Casierra-Posada \& Peña-Olmos, 2015), as the ones found in this study.

The influence of shading can be confirmed by taller trefoil insertion under opaque and green covers (high opacity). However, the authors found a contradiction here, since the blue treatment, which also presents high shading, showed intermediate height of trefoil insertion and internode etiolation. Similarly, the stolon emission was lower under the green and blue covers (high opacity) and intermediate under the opaque cover (also with high opacity).

The same looks occur with production components, wherein shading does not give all responses, because even the transparent cover showing higher production in low shading, the opaque cover also obtained one of the larger productions, showed higher shading as well as the green cover, which, on the contrary, was responsible for the worst productivity values. Such contradictory results show that besides the influence of shading, spectral quality plays an important role in such traits. Analogously, the control without shading, did not show proportional increase in production as it happened in the transparent treatment; however, in this case, it is possible that other factors had influenced the answers, like as washing pollen from flowers and fruit rotting due to the fact that rainfall directly influences production. Moreover, as the responses to luminosity changes are complex, the smallest height of trefoil insertion and etiolation under transparent cover and the control could have happened because of the excess of light, which interferes on hormone action, like auxin which is photodegradable and has its concentration inversely related to the amount of light and temperature (Stamm \& Kumar, 2010).

These results corroborate the studies carried out by Casierra-Posada et al. (2011, 2012) which, besides shading, a strong influence of green cover on decreasing the production and stimulating the strawberry vegetative growth was noticed, specifically the investment in leaves and aboveground part, in detriment of fruits and flowers. Considering the responses obtained, the authors could infer that, although production is linked to both factors, the spectral quality exerts influence greater than the incident light intensity.

Another aspect related to the influence of spectral quality was the

Table 1. Microclimatic conditions and opacity under low tunnels of different colors. Guarapuava, UNICENTRO, 2014/2015.

\begin{tabular}{lccccc}
\hline Cover & $\begin{array}{c}\text { Average temperature } \\
\left({ }^{\circ} \mathrm{C}\right)\end{array}$ & $\begin{array}{c}\text { Thermal amplitude } \\
\left({ }^{\circ} \mathbf{C}\right)\end{array}$ & $\begin{array}{c}\text { Soil temperature } \\
\left({ }^{\circ} \mathrm{C}\right)\end{array}$ & $\begin{array}{c}\text { Relative humidity } \\
(\%)\end{array}$ & $\begin{array}{c}\text { Opacity } \\
(\%)\end{array}$ \\
\hline Red & 24.0 & 23.1 & 22.4 & 59.1 & 71.1 \\
Blue & 24.0 & 22.1 & 21.8 & 60.4 & 81.0 \\
Yellow & 24.2 & 23.2 & 22.1 & 61.6 & 68.4 \\
Green & 24.6 & 23.8 & 21.7 & 60.3 & 75.1 \\
Opaque & 23.5 & 20.2 & 21.6 & 59.7 & 81.3 \\
Transparent & 26.0 & 25.5 & 22.7 & 60.8 & 30.7 \\
Control & 23.4 & 20.7 & 22.5 & 60.7 & 0.0 \\
\hline
\end{tabular}




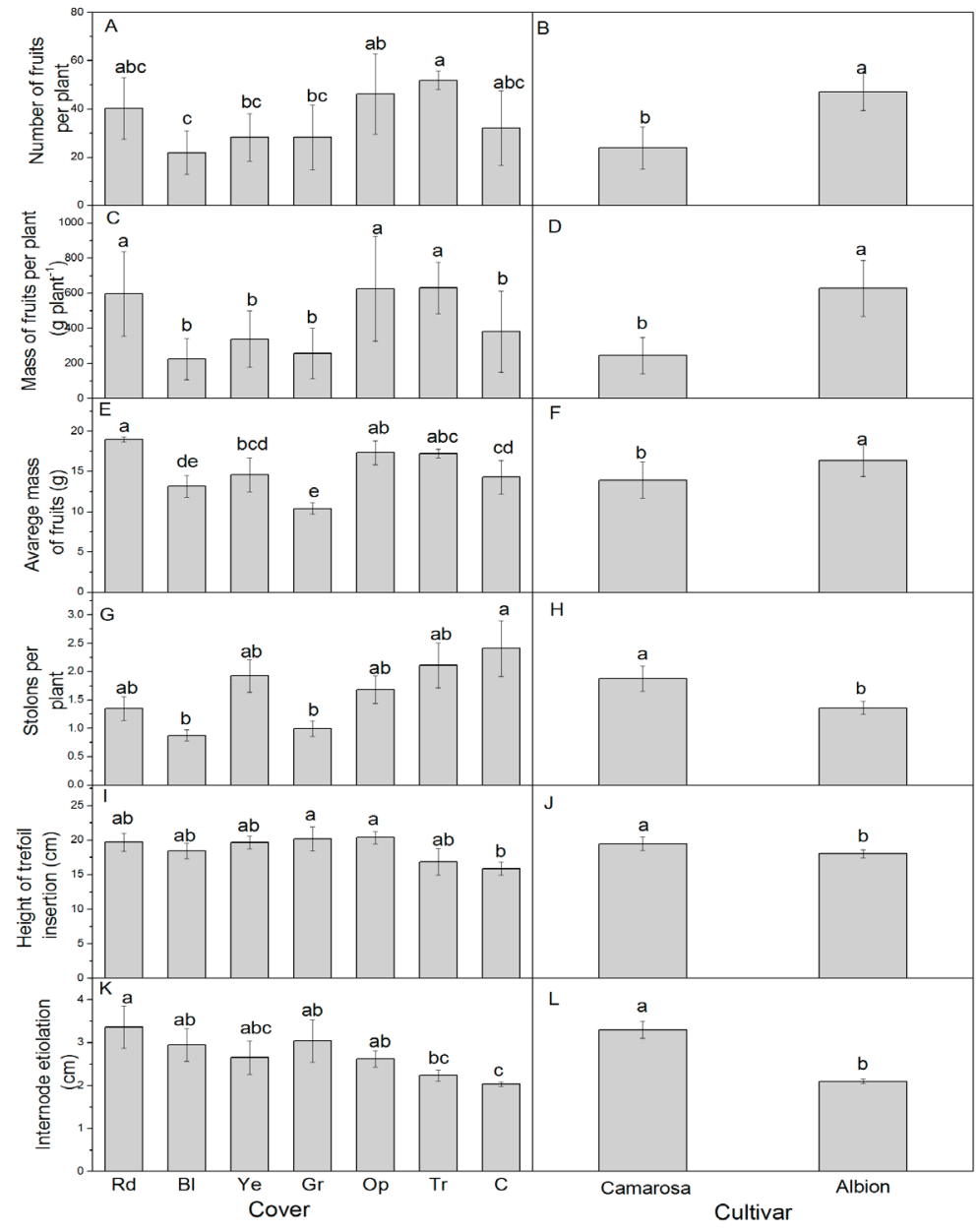

Figure 1. Total production, average mass of fruit, stolon emission, height of trefoil insertion and plant etiolation of two strawberry cultivars grown under low tunnels with different colored covers: Red (Rd); Blue (Bl); Yellow (Ye); Green (Gr); Opaque (Op); Transparent (Tr); and Control (C). The bars refer to standard error. Averages followed by the same letter do not differ statistically by Tukey test $(\mathrm{p}<0.05)$. Guarapuava, UNICENTRO, 2014/2015.

greater internode etiolation found under the red cover, which can be explained by the relationship between red light:far red ratio $(\mathrm{V}: \mathrm{VD})$ in phytochromeinduced responses, since in conditions of low V:VD and low photosynthetically active radiation, petiole and internode elongation, as well as promotion of apical dominance can be noticed (Casierra-Posada et al., 2012). This fact suggests that the red cover decreased the radiation availability in the red band $(650$ to $680 \mathrm{~nm})$ and increase in the far red band (710 to $740 \mathrm{~nm}$ ), simulating the response to shading. The authors expected that the energy for growth/ etiolation lead to lower fruit production, however, the red cover provided high production and average fruit mass when compared to the yellow, blue, green covers and the control. This fact can be explained because of another physiological function of the red light: the floral induction (Samuoliené et al., 2010).

The data of the quality of postharvest show that the external luminosity and chromaticity were influenced by cultivar variation (Table 2), whereas the cover influenced the external hue angle and the internal luminosity. The authors observed significant interactions between color and cultivars for internal hue, soluble solids, titratable acidity, ratio (SS/AT), phenolic compounds, anthocyanins and ascorbic acid.
The authors verified that the highest soluble solid concentration occurred in unshaded treatments (Camarosa) and transparent (Albion) which showed the lowest shading. This fact shows that the synthesis of soluble solids may be related to luminous incidence. However, soluble solids are represented, mainly, by sugars (Antunes et al., 2014) and, thus, their content is linked to photosynthetic process. Since strawberry is a C3 plant, high temperatures can cause stomatal closing, and consequently a decrease in production of photosynthates. However, Albion showed the highest ${ }^{\circ}$ Brix under the transparent treatment, which showed the highest microclimatic temperature $\left[2.6^{\circ} \mathrm{C}\right.$ higher than the average temperature of the control (Table 1)]. This indicates that soluble solid accumulation, in this case, was more influenced by quantity of radiation than by photosynthesis, since shading could have been limiting for the other treatments, since the soluble solids concentration was lower in the treatments with higher opacity (opaque and blue). This fact is corroborated by Cui et al. (2009) which affirm that light can be used to improve the quality of strawberry, by influences on biosynthesis and soluble solid accumulation. This is also in accordance with the conclusions of Casierra-Posada et al. (2011) reporting that the highest soluble solids content is related to irradiance.

Concentration of organic acids is an important trait for fruit quality attributes. Moreover, the presence of these organic acids helps to regulate $\mathrm{pH}$ and stabilizes other molecules like anthocyanins and ascorbic acid, for example (Wang et al., 2009). The results for titratable acidity (Figure 2) show that the fruits grown under the yellow cover showed fruit acidity, higher than the others in both cultivars. Contrary to the results found, Casierra-Posada et al. (2011), using colored polyethylene film as plant cover, observed that fruits grown under the yellow cover showed fruit with lower acidity. Cui et al. (2009) highlighted that wavelengths in less operative bands of photosynthesis, such as yellow and green, for example, can also alter the concentration of 
phytochemical compounds such as organic acids, through its action on different photoreceptors.

Ratio between soluble solid and titratable acidity represents the balance between sweetness and acidity, being an important indicator of fruit quality (Resende et al., 2010). The unfolding interaction (Figure 2) showed that Camarosa presented higher SS/AT ratio in fruits grown without cover, which is related to its higher soluble solids content, as mentioned before, may be linked to higher luminous incidence. On the other hand, the fact that the fruits of Albion produced under green cover and the fruits of Camarosa under red cover present high SS/AT ratio, suggests that these colors may present interaction with intrinsic traits of cultivars, since that the increase of ratio was isolated.
The results found for content of bioactive compounds of fruits of Albion and Camarosa show different response when produced under colored covers, indicating that the synthesis and accumulation of these compounds are linked to the cultivar genotypes, which makes the interpretation of observed responses complex, since each cultivar responds in a different way to the environmental factors.

$\mathrm{Xu}$ et al. (2014) highlighted that blue light increases the content of phenolic compounds, ascorbic acid and anthocyanins, due to the antioxidant capacity of these compounds, which act as a UV light filter. This can explain the results found under the blue cover, for anthocyanins and ascorbic acid, which showed high levels in fruits of Camarosa and Albion, respectively.
On the other hand, Samuoliené et al. (2010) concluded that light in the spectrum of blue and red is necessary for appropriate accumulation of phenolic compounds, anthocyanins and ascorbic acid; however, the addition of other light qualities may increase the level of the compounds in plants. This can be explained through the results found in Camarosa, in which the red (phenolic compounds) and blue covers (anthocyanins and ascorbic acid) increased the contents of these compounds. According to the same authors, UV light increase the levels of phenols, whereas the addition of green light increases the concentration of anthocyanins. This fact was not observed in this study, because there was no considerable increase in phenolic compounds in fruits under blue cover

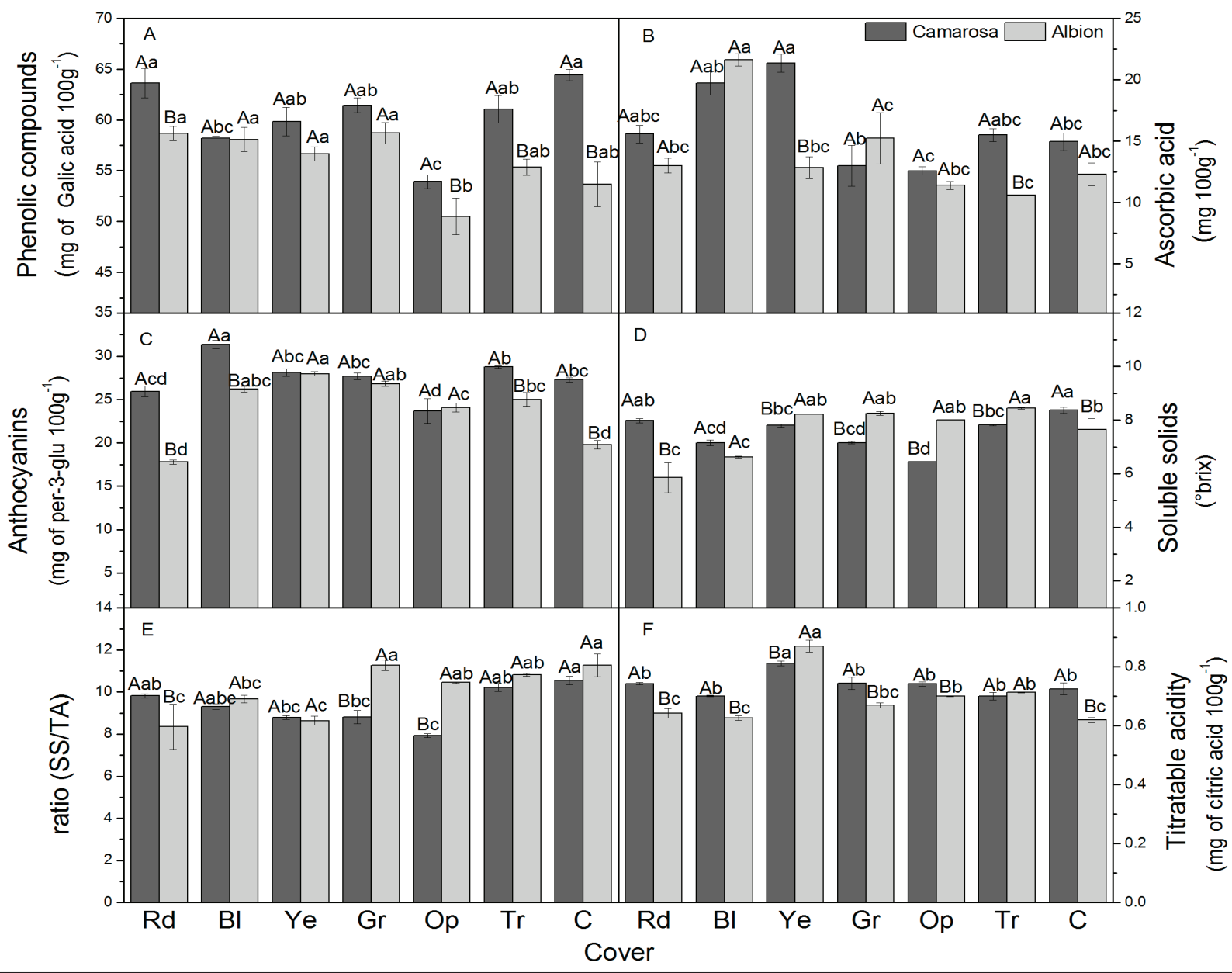

Figure 2. Post-harvest traits of two strawberry cultivars grown under low tunnels with different colored covers: Red (Rd); Blue (Bl); Yellow (Ye); Green (Gr); Opaque (Op); Transparent (Tr); and Control (C). The bars refer to standard error. Averages followed by the same letter do not differ statistically by Tukey test $(\mathrm{p}<0.05)$. Guarapuava, UNICENTRO, 2015. 
Table 2. Internal and external color of two strawberry cultivars grown under low tunnels with different colored covers. Guarapuava, UNICENTRO, 2015.

\begin{tabular}{|c|c|c|c|c|}
\hline \multirow{2}{*}{ Cover } & \multicolumn{4}{|c|}{ External color } \\
\hline & \multicolumn{2}{|l|}{ Luminosity } & Chroma & ${ }^{\circ} \mathrm{Hue}$ \\
\hline Red & \multicolumn{2}{|l|}{32.57} & 29.64 & $24.46 \mathrm{ab}$ \\
\hline Blue & \multicolumn{2}{|l|}{33.61} & 31.26 & $23.31 \mathrm{ab}$ \\
\hline Yellow & \multicolumn{2}{|l|}{33.23} & 29.29 & $27.48 \mathrm{a}$ \\
\hline Green & \multicolumn{2}{|l|}{33.32} & 29.87 & $23.08 \mathrm{ab}$ \\
\hline Opaque & \multicolumn{2}{|l|}{33.26} & 31.03 & $25.06 \mathrm{ab}$ \\
\hline Transparent & \multicolumn{2}{|l|}{32.57} & 30.29 & $23.49 a b$ \\
\hline Control & \multicolumn{2}{|l|}{32.12} & 27.19 & $20.51 \mathrm{~b}$ \\
\hline Camarosa & \multicolumn{2}{|l|}{$33.59 \mathrm{a}$} & $31.05 \mathrm{a}$ & 23.70 \\
\hline Albion & \multicolumn{2}{|l|}{$32.32 \mathrm{~b}$} & $28.54 \mathrm{~b}$ & 24.10 \\
\hline \multirow[t]{2}{*}{ CV (\%) } & \multicolumn{2}{|l|}{5.63} & 0.16 & 31.53 \\
\hline & \multicolumn{4}{|c|}{ Internal color } \\
\hline \multirow[t]{2}{*}{ Cover } & \multirow{2}{*}{ Luminosity } & \multirow{2}{*}{ Chroma } & \multicolumn{2}{|c|}{${ }^{\circ} \mathrm{Hue}$} \\
\hline & & & Camarosa & Albion \\
\hline Red & $42.72 \mathrm{c}$ & 32.31 & $42.21 \mathrm{Abc}$ & $44.5 \mathrm{~A}$ \\
\hline Blue & $42.56 \mathrm{c}$ & 33.85 & $38.29 \mathrm{Bc}$ & $46.8 \mathrm{~A}$ \\
\hline Yellow & $49.94 \mathrm{a}$ & 32.08 & $41.22 \mathrm{Abc}$ & $44.7 \mathrm{~A}$ \\
\hline Green & $43.35 \mathrm{bc}$ & 35.04 & $48.63 \mathrm{Aa}$ & $47.8 \mathrm{~A}$ \\
\hline Opaque & $48.17 \mathrm{ab}$ & 34.74 & 45.57 Aab & $47.1 \mathrm{~A}$ \\
\hline Transparent & $46.16 \mathrm{abc}$ & 33.33 & 43.70 Aabc & $46.1 \mathrm{~A}$ \\
\hline Control & $44.81 \mathrm{abc}$ & 33.96 & 45.34 Aab & $45.3 \mathrm{~A}$ \\
\hline Camarosa & 44.83 & $34.84 \mathrm{a}$ & & 56 \\
\hline Albion & 45.94 & $32.39 \mathrm{~b}$ & & 04 \\
\hline CV (\%) & 8.47 & 32.31 & & 32 \\
\hline
\end{tabular}

Averages followed by different lowercase letters in columns differ significantly, at $5 \%$ probability, by using the Tukey test.

neither in anthocyanins under green cover. Another observed aspect was the increase of ascorbic acid in fruits of Camarosa grown under yellow cover, which shows a probable interaction between the cultivar and the color. Moreover, this concentration can be related to the high acidity found in these fruits.

The levels of phenolic compounds obtained corroborate the results of Choi et al. (2015), which indicated an increase in the levels of phenolic compounds in strawberries grown under the red light. However, in the present study, the authors found an increase in anthocyanin under treatment with red and blue light: the red light did not generate increase in anthocyanin.
In relation to the color of the fruits, the authors verified that the fruits of Camarosa showed higher values of luminosity and internal and external chroma. This demonstrates that the fruits showed more intense and bright color than the cultivar Albion, since the luminosity $\left(\mathrm{L}^{*}\right)$ ranges from 0 (black) to 100 (white) and the chroma $\left(\mathrm{C}^{*}\right)$ ranges from 0 (opaque) to 60 (pure color) indicating color saturation. The hue value ranges from $0^{\circ}$ to $180^{\circ}$, considering that the closest to $0^{\circ}$, more intense red is the color of the fruit (Sui et al., 2016).

Among all the colors of covers tested, the one which provided the lowest value of external ${ }^{\circ}$ hue (the most intense color) was the control, differing statistically from the yellow. For internal color, the lowest values of $\mathrm{L}^{*}$ could be noticed in fruits grown under blue and red covers, which differed statistically from the opaque and the yellow. The unfolding which was carried out for the interaction found in internal ${ }^{\circ}$ hue, demonstrated that the colors did not influence its value in cultivar Albion, however, for Camarosa, the blue cover provided lower ${ }^{\circ}$ hue (more intense color). Considering that the authors obtained fruits with more intense and darker color under the blue cover, it is possible that blue light, which is characterized by being more energetic, could have caused the browning of the fruits through degradation of the cells or due to promote stimulation of synthesis of anthocyanin, which acts as a photoprotector and gives the characteristic red color (Bian et al., 2014).

In this study, the authors verified that the changes in quality and quantity of luminosity, under low tunnels with different colored films, influenced vegetative, productive and fruit quality traits. And that the cultivars Camarosa and Albion respond differently to luminosity. In isolation, Camarosa presented more developed vegetative traits, more concentration of bioactive compounds and fruits showing more intense color. Albion showed higher production. Thus, in relation to the traits evaluated in this study, Camarosa showed better quality of fruits and smaller production comparing with Albion.

In relation to colored covers, the authors observed that green cover was the one which stimulates the vegetative traits in detriment of production, whereas the red cover influenced the etiolation and production of the fruits. When using the transparent and opaque covers, together with the red, the authors obtained plants with best fruit production. The covers which provided the best fruit quality, in general, were the yellow and blue covers and the control. The results obtained under colored covers were not considerably superior to the ones obtained under transparent and opaque covers. Thus, the colored covers were not considered 
promising for production dedicated for fresh consumption. Thus, the authors suggest the use of covers which have already been used commercially. Except in cases in which, a specific response is expected like an increase in a specific compound, in which the covers can be used satisfactorily.

In short, although the light intensity seems to have a greater effect on vegetative traits and light quality seems influence fruit production and quality, the responses found demonstrate to be related to microclimatic conditions, luminous incidence and spectral quality.

\section{ACKNOWLEDGEMENT}

The authors thank to Coordenação de Aperfeiçoamento de Pessoal de Nível Superior (CAPES) (National Council for Scientific and Technological Development) for financial support and for the Master scholarship.

\section{REFERENCES}

ANDERS, K; ESSEN, LO. 2015. The family of phytochrome-like photoreceptors: diverse, complex and multi-colored, but very useful. Current Opinion in Structural Biology 35: 7-16.

ANTUNES, MC; CUQUEL, FL; ZAWADNEAK, MAC; MOGOR, AF; RESENDE, JTV. 2014. Postharvest quality of strawberry produced during two consecutive seasons. Horticultura Brasileira 32: 168-173.

BASU, A; NGUYEN, A; BETT, NM; LYONS, TJ. 2014. Strawberry as a functional food: an evidence-based review. Critical Reviews in Food Science and Nutrition 54: 790-806.

BENASSI, MT; ANTUNES, AJ.1998. A comparison of methaphosphoric and oxalic acids as extracts solutions for the determination of vitamin $\mathrm{C}$ in vegetables. Arquivos de Biologia e Tecnologia 31: 507-513.

BIAN, ZH; YANG, QC; LIU, WK. 2014. Effects of light quality on the accumulation of phytochemicals in vegetables produced in controlled environments: a review. Journal of the Science of Food and Agriculture 95: 869-877.

CARVALHO, SP; ZAWADNEAK, MAC; ANDRADE, PFS; ZANDONÁ, JC. 2014. $O$ cultivo do morangueiro no Brasil. In: ZAWADNEAK, MAC; SCHUBER, JM; MÓGOR, AF. Como produzir morangos. Curitiba: UFPR. p. 15-68.

CASIERRA-POSADA, F; PEÑA-OLMOS, JE. 2015. Modificaciones fotomorfogénicas inducidas por la calidad de la luz en plantas cultivadas. Revista de la Academia Colombiana de Ciencias Exactas, Físicas y Naturales 39: 84-92.

CASIERRA-POSADA, F; PEÑA-OLMOS, JE; ULRICHS, C. 2012. Basic growth analysis in strawberry plants (Fragaria sp.) exposed to different radiation environments. Agronomía Colombiana 30: 25-33.

CASIERRA-POSADA, F; PEÑA-OLMOS, JE; VARGAS-MARTÍNEZ, AF. 2011. Physical and chemical properties of strawberries (Fragaria sp.) grown under photoselective filters. Revista Facultad Nacional de Agronomía Medellin 64: 6221-6228.

CHOI, HG; MOON, BY; KANG, NJ. 2015. Effects of LED light on the production of strawberry during cultivation in a plastic greenhouse and in a growth chamber. ScientiaHorticulturae 189: 22-31.

CUI, J; MA, ZH; XU, ZG; ZGANG, H; CHANG, TT; LIU, HJ. 2009. Effects of supplemental lighting with different light qualities on growth and physiological characteristics of cucumber, pepper and tomato seedlings. Acta Horticulturae Sinica 5: 663-670.

DURNER, EF. 2015. Photoperiod affects floral ontogeny in strawberry (Fragaria $\times$ ananassa Duch.) plug plants. Scientia Horticulturae 1: 154-159.

EMBRAPA - Empresa Brasileira de Pesquisa Agropecuária. 2013. Sistema brasileiro de classificação de solos. 3ed. Rio de Janeiro: Embrapa Solos. 353p.

FERREIRA, DF. 2010. SISVAR - Sistema de análise de variância. Versão 5.3. Lavras-MG: UFLA.

GIUSTI, MM; WROLSTAD, RE. 2001. Anthocyanins: characterization and measurement with UV-visible spectroscopy. In: WROLSTAD, RE. Current protocols in food analytical chemistry. New York: John Wiley and Sons. p. 1-13.

HEIDE, OM; STAVANG, JA; SONSTEBY, A. 2013. Physiology and genetics of flowering in cultivated and wild strawberries - a review. Journal of Horticultural Science and Biotechnology 88: 1-18.

INSTITUTO ADOLFO LUTZ. 2005. Normas analíticas do Instituto Adolfo Lutz. Métodos fisico-químicos para análise de alimentos. 4. ed. Brasília: Ministério da Saúde, Agência Nacional de Vigilância Sanitária. 1018p.

PÁDUA, JG; ROCHA, LCD; GONÇALVES, ED; ARAÚJO, TH; CARMO, EL; COSTA, R. 2015. Comportamento de cultivares de morangueiro em Maria da Fé e Inconfidentes, sul de Minas Gerais. Revista Agrogeoambiental 7: 69-79.

PIERIK, R; WIT, M. 2014. Shade avoidance: phytochrome signalling and other aboveground neighbour detection cues. Journal of Experimental Botany 65: 2815-2824.

RESENDE, JTV; MORALES, RGF; FARIA, MV; RISSINI, ALL; CAMARGO, LKP; CAMARGO, CK. 2010. Produtividade e teor de sólidos solúveis de frutos de cultivares de morangueiro em ambiente protegido. Horticultura Brasileira 28: 185-189.

SAMUOLIENE, G; BRAZAITYTE, A; URBONAVICIUTE, A; SABAJEVIENE, G; DUCHOVSKIS, P. 2010. The effect of red and blue light component on the growth and development of frigo strawberries.Zemdirbyste Agriculture 97: 99-104.

STAMM, P; KUMAR, PP. 2010. The phytohormone signal network regulating elongation growth during shade avoidance. Journal of Experimental Botany 61: 28892903.

SUI, X; BARY, S; ZHOU, W. 2016.Changes in the color, chemical stability and antioxidant capacity of thermally treated anthocyanin aqueous solution over storage. Food Chemistry 192: 516-524.

WANG, H; GU, M; CUI, J; SHI, K; ZHOU, Y; YU, J.2009. Effects of light quality on $\mathrm{CO}_{2}$ assimilation, chlorophyll-fluorescence quenching, expression of Calvin cycle genes and carbohydrate accumulation in Cucumis sativus. Journal of Photochemistry and Photobiology 96: 30-37.

WOISKY, RG; SALATINO, A. 1998. Analysis of propolis: some parameters and procedures for chemical quality control. Journal of Apicultural Research 37: 99-105.

XU, F; SHI, L; CHEN, W; CAO, S; SU, X; YANG, Z. 2014. Effect of blue light treatment on fruit quality, antioxidant enzymes and radical-scavenging activity in strawberry fruit. Scientia Horticulturae 175: 181-186. 